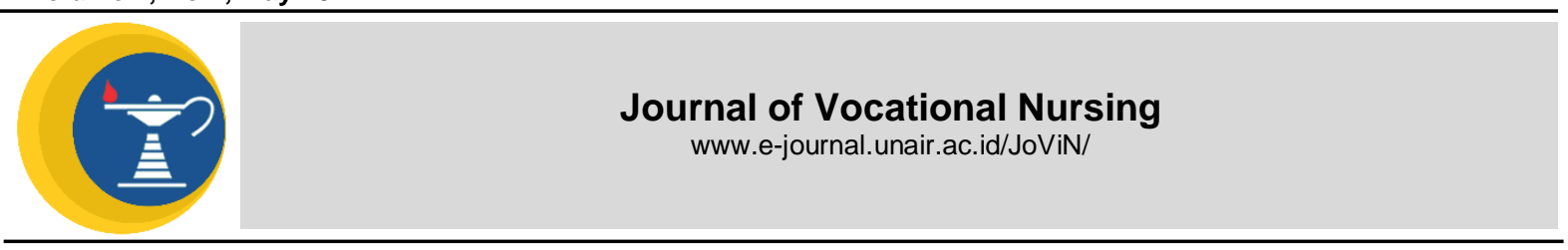

\title{
DESCRIPTION OF HYPERTENSION LEVELS IN PRIMARY HYPERTENSION ADULTS AND ELDERLY IN KARANGBINANGUN LAMONGAN DISTRICT
}

\author{
Iswatun ${ }^{1}$, Endah Sri Wijayanti², Lailatul Fadliyah³ ${ }^{3}$ Cucuk Rahmadi Purwanto ${ }^{4}$, lin \\ Rohmawati ${ }^{5}$ \\ 1,23,4 Faculty of Vocational Studies, Universitas Airlangga \\ ${ }^{5}$ Faculty of Health Universitas Muhammadiyah Lamongan
}

Research Report

\section{A B S TRACT}

Introduction: Hypertension is often a silent killer because it is often without symptoms that warn of a problem. Symptoms that appear are often considered as common disorders, so that the victim is too late to realize that the disease is coming. Hypertension is an increase in blood pressure above normal limits with systolic value of $140 \mathrm{mmHg}$ and diastolic value of $90 \mathrm{mmHg}$. The purpose of this study was to determine the level of hypertension in patients with primary hypertension in Karangbinangun Lamongan District. Method: This research design using descriptive with a population of 70 respondents then sampled using simple random sampling and get a sample of 64 respondents, in accordance with the inclusion criteria, are healthy patients and willing to sign the informed consent The variable in this study is the level of hypertension. The data of this study were taken from the results of blood pressure measurements by standards WHO. The data is tabulated in the form of frequency distribution by categorizing hypertension into mild, moderate and severe. Result: The results showed that half of the respondents (50\%) had mild hypertension, $28.1 \%$ moderate hypertension and $21.9 \%$ severe hypertension. Conclusion: Seeing the results of this study, that there are still many people who have hypertension, so health education by health workers and family is needed to prevent recurrence.
ARTICLE INFO

Received April 26, 2021

Accepted May 30, 2021

Online May 31, 2021

*Correspondence:

Iswatun

*Email:

ibuiswatun@gmail.com

Keywords:

Hypertension, Primary

Hypertension, Adults, Elderly

\section{INTRODUCTION}

Hypertension is a medical condition in the form of an increase in blood pressure above normal limits. Hypertension is an increase in blood pressure above normal limits with a systolic value of $140 \mathrm{mmHg}$ and a diastolic value of $90 \mathrm{mmHg}$. To confirm hypertension by measuring blood pressure. The normal limits are $120-140 \mathrm{mmHg}$ cytolic and $80-90 \mathrm{mmHg}$ diastolic. So, someone is said to have hypertension if their blood pressure is above 140/90 mmHg (El Manan, 2011).

Hypertension is found in two types, namely primary hypertension and secondary hypertension. Primary hypertension usually begins gradually without complaints and symptoms as a benign disease which gradually progresses to a malignant state. Meanwhile, secondary hypertension is caused by renal disease or other identifiable causes (Kowalak, 2011).

Hypertension is the number one cause of death in the world. Data from the Join
National Committee on Prevention, Detection, Evaluation, and Treatment on High Blood Presure VII said that nearly 1 billion people in the world have hypertension (Prasetyaningrum. Y.I, 2014).

According to the records of the World Health Organization (WHO), around the world around 972 million people or $26.4 \%$ have hypertension, this figure is likely to increase to $29.2 \%$ in 2025 . From the data of 972 million people with hypertension, 333 million are in developing countries, including Indonesia. Primary hypertension is the most common type and includes $35 \%-95 \%$ of the hypertensive population, while secondary hypertension accounts for $5 \%-15 \%$ of the hypertensive population. Hypertension is a cause of death which reaches $6.7 \%$ of the hypertensive population, at all ages in Indonesia (Hestiantica, 2017).

While the results of the initial survey conducted in Karangbinangun Lamongan District, obtained data from 10 people who had 
blood pressure checks, there were 5 (50\%) people who had mild hypertension, 2 (20\%) people had moderate hypertension, 1 (10\%) people had severe hypertension and 2 (20\%) others had normal blood pressure. The average blood pressure of those suffering from hypertension ranged from: systolic pressure 150-190 $\mathrm{mmHg}$ and diastolic pressure 90-110 $\mathrm{mmHg}$.

Some risk factors for hypertension that cannot be avoided or changed include race, age, gender and family history. While factors that can be avoided because they can aggravate hypertension include obesity, lack of physical activity, smoking, sodium sensitivity, low potassium levels, excessive drinking, and stress (Dalimartha, 2008).

Increasing blood pressure causes the heart to work extra hard, if suffered for a long time it can cause various kinds of complications. High blood pressure can damage the inside of the tiny arteries, possibly causing blood clots. This happens and can lead to heart attacks, blindness, kidney failure and strokes (Nurul, 2011).

Hypertension can be controlled until it reaches normal and stable values. Hypertension can be minimized with pharmacological and non-pharmacological therapy actions that can help prevent or delay the occurrence of health problems due to hypertension. The purpose of this study was to determine the level of hypertension in patients with primary hypertension in Karangbinangun Lamongan District.

\section{MATERIALS AND METHODS}

This research design uses descriptive method with a population of 70 respondents. Samples were taken from people suffering from hypertension who were in Karangbinangun Lamongan District, then the samples were taken using simple random sampling and getting a sample of 64 respondents, in accordance with the inclusion creteria. The criteria for the inclusion are healthy patients and willing to sign the informed consent.

The variable in this study is the level of hypertension. The validity value is very high because the data of this study were taken from the results of blood pressure measurements, the gouped by standards WHO. Before the measurement, the patient was explained in the purpose of measuring blood pressure, then the patient was asked to sign an informed consent.

According to $\mathrm{WHO}$, it is said that hypertension is mild if the systole is $140-159$ $\mathrm{mmHg}$ and diastole is $90-99 \mathrm{mmHg}$. Medium hypertension when systole 160-179 $\mathrm{mmHg}$ and diastole 100-109 $\mathrm{mmHg}$. Severe hypertension when systole $>180 \mathrm{mmHg}$ and diastole 110$119 \mathrm{mmHg}$. The data is tabulated in the form of frequency distribution by categorizing hypertension into mild, moderate and severe.

\section{RESULTS}

Table 1 shows that the majority of respondents were female (81.3\%), age $51-60$ years $(37,5 \%)$ and level education primary school $(54,6 \%)$.

Table 1 Distribution of respondent based on the characteristics of Gender, Age and Level Education

\begin{tabular}{lll}
\hline Characteristics & Frequency & Percentage \\
\hline Gender & & \\
Male & 12 & 18,8 \\
Female & 52 & 81,3 \\
\hline Age (th) & & \\
$41-50$ & 10 & 15,6 \\
$51-60$ & 24 & 37,5 \\
$61-70$ & 16 & 25,0 \\
$>70$ & 14 & 21,9 \\
\hline Level Education & & \\
No School & 8 & 12,5 \\
Primary School & 35 & 54,6 \\
Junior School & 10 & 15,6 \\
Senior School & 6 & 9,3 \\
Diploma/College & 5 & 7,8 \\
\hline
\end{tabular}

Table 2 shows that 32 people (50\%) had mild hypertension, while 14 (21.9\%) had severe hypertension.

Table 2 Distribution of Hypertension Levels in Primary Hypertension Patients in Karangbinangun Lamongan District 


\begin{tabular}{lll}
\hline Blood Pressure & Frequency & Percentage \\
\hline Mild hypertension & 32 & 50,0 \\
Moderate hypertension & 18 & 28,1 \\
Severe hypertension & 14 & 21,9 \\
\hline
\end{tabular}

\section{DISCUSSION}

Based on table 2, it shows that 32 people with hypertension had mild hypertension (50\%), possibly due to heredity and lifestyle. Apart from these two factors, other factors that can affect hypertension are age, gender, occupation and possibly the education level of the respondents, because minimal education can affect the lifestyle and daily activity patterns of each individual. At the time of the study, almost all hypertensive patients were women.

Table 1 shows that there are 52 female patients with hypertension (81.3\%). It can be concluded that hypertension is more common in women than men. In the beginning, hypertension affects men more easily than women, this is probably because men have many driving factors for hypertension, such as stress, fatigue and uncontrolled eating. But this will happen on the contrary after entering menopause hypertension in women will increase due to hormonal factors (Dalimartha, 2008).

Gender greatly influences the occurrence of hypertension because it is influenced by hormonal imbalances, where during menopause in women the cells will lose the hormone estrogen so that it affects the elasticity of blood vessels and work on the cardiovascular system, so women are more likely to have high blood pressure. Likewise, Patients with hypertension must also pay attention to diet, lifestyle, activity, always exercising, reducing stress, smoking and reducing salt so that the increase in blood pressure can be controlled. Research conducted at RSI Palembang, that there is a significance between the sexes on the incidence of hypertension (Aristoteles, 2018). This is different from the research conducted in Talang Empat, Bengkulu which stated that there was no relationship between sex and the incidence of hypertension(Wicaksono, 2015). Apart from gender, hypertension is more prone to occur in old age. Increasing age can increase the risk of contracting hypertension, although hypertension can occur at any age but most commonly occurs in adults aged 35 years or over.

Table 1 shows that the majority of hypertensive patients aged 51-60 years $(53.1 \%)$. This is in line with research in Tangerang City that age is a dominant factor affecting the incidence of hypertension (Nuraeni, 2019). Likewise, research conducted in the city of Bitung, North Sulawesi, shows that there is a significance between age and the incidence of hypertension (Tamamilang et al., 2019).

Increasing blood pressure with age is very natural, this is due to natural changes in the heart, blood vessels, and hormone levels. In old age, they are more susceptible to hypertension because in old age the arteries are harder and less flexible to the blood, which can lead to an increase in systolic blood pressure (Dalimartha, 2008). This is due to the many physiological decreases in the function of the body's system with increasing age, because in old age blood vessels have started to lose elasticity, so that it can affect the work of the cardiovascular system and can lead to hypertension, so that in old age it is more susceptible to hypertension.

Table 1 shows that most of the respondents have primary school education (54.6\%). Education also affects the incidence of hypertension. Hypertension. Research conducted in Ratahan, Minahasa stated that there is a relationship between education and the incidence of hypertension (Periode, Mei, Waas, Ratag, \& Umboh, 2014). Patients with hypertension must also pay attention to diet, lifestyle, activity, always exercising, reducing stress, smoking and reducing salt so that the increase in blood pressure can be controlled.

\section{CONCLUSION}

Half of the respondents, $50 \%$ had mild hypertension, $28.1 \%$ moderate hypertension and $21.9 \%$ had severe hypertension. So health education is needed for the community to prevent recurrence. Further research is needed to find the factors that cause hypertension in adult and elderly patients. And a qualitative study was conducted to explore the causes of hypertension

\section{REFERENCES}

Aristoteles. (2018). Korelasi umur dan jenis kelamin dengan penyakit hipertensi di emergency center unit Rumah Sakit Islam Siti Khadijah Palembang 2017. Indonesia Jurnal Perawat, 3(1), 9-16.

Dalimartha, S. (2008). Care Your Self Hipertensi. Jakarta: Penebar Plus.

El Manan, M. (2011). Basmi Keluhan-Keluhan Kesehatan Harian Dengan Obat-Obat Alami. Jogyakarta: FlashBooks. 
Hestiantica, D. (2017). Hubungan Pengetahuan dan Riwat hipertensi Dengan Tindakan Pengendalian Tekanan Darah Pada Lansia Di Kelurahan Ampel RW 5 RT 1-5. FKM. Unair.

Kowalak, J. P. (2011). Buku Ajar Patofisiologi. Jakarta: EGC. Jakarta: EGC.

Nuraeni, E. (2019). Hubungan Usia Dan Jenis Kelamin Beresiko Dengan Kejadian Hipertensi Di Klinik X Kota Tangerang. Jurnal JKFT, 4(1), 1. https://doi.org/10.31000/jkft.v4i1.1996

Nurul, W. (2011). Menaklukan Hipertensi dan Diabetes. (Multipress, ed). Yogyakarta.

Periode, T., Mei, D., Waas, F. L., Ratag, B. T., \& Umboh, J. M. L. (2014). Hipertensi di setiap Puskesmas se-Provinsi Sulawesi Utara Melalui data. 6.

Prasetyaningrum. Y.I. (2014). NHipertensi Bukan Untuk Ditakuti. Jakarta: FMedia.

Tamamilang, C. D., Kandou, G. D., Nelwan, J. E., Kesehatan, F., Universitas, M., \& Ratulangi, S. (2019). Hubungan Antara Umur Dan Aktivitas Fisik Dengan Derajat Hipertensi Di Kota Bitung Sulawesi Utara. Kesmas, 7(5).

Wicaksono, S. (2015). Lansia Dengan Peningkatan Tekanan Darah (Hipertensi) Di Dusun 1 Desa Kembangseri Kecamatan Talang Empat Bengkulu Tengah Tahun 2015. Fakultas Kedokteran Dan IImu Kesehatan Universitas Bengkulu, 1-6. 